\title{
$\mathrm{N}$ 病院手術部におけるサーキュ レーションの分析 \\ 一急性期病院手術部の持続的改善手法 の実践 その $1-$
}

\section{ANALYSIS OF CIRCULATION PATTERNS WITHIN HOSPITAL "N"}

- Sustainable improvement of surgical departments in acute care hospitals Part 1 -

\section{河合慎介— $* 1$ 小菅瑠香 —— $* 2$ \\ キーワード : \\ 急性期病院, 手術部, ファシリティマネジメント, 持続的改善,} 看護動線

Keywords:

Acute care hospital, Surgical department, Facility management, Sustainable improvement, Nursing activity

\section{Shinsuke KAWAI — $* 1 \quad$ Ruka KOSUGE-_ $* 2$}

This report focuses on the surgical departments of acute care hospitals as a key factor in high turnover procedures. The aim is to analyze current nursing activities in order to optimize logistics flow. Four nurses were followed and observed in each duty. We divided their jobs into seven categories: preparation, surgical assistance, clean-up, logistics management, information, operations and others, and also analyzed each job time and travel distance. The data obtained will be compared with that in subsequent studies.

\section{1. 研究の背景と目的}

近年, 厚生労働者は医療施策の基本方針として地域完結を目指し

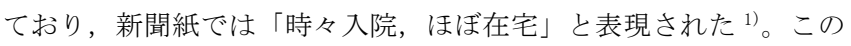
フローは, 医療必要度が高い患者を集中的に急性期病院の短期間入 院で治療, その状態を脱した後のフォローの入院, そして退院後の 在宅で受ける医療・看護もしくはかかりつけ医の外来一の通院とな る。この方針は具体的に, 在宅医療の担い手となる在宅療養支援病 院 (2010 年), 退院患者割合の要件を追加した 7 対 1 病棟 (2014 年), 在宅復帰率の要件が付随した地域包括ケア病棟 (2014 年), 回復期リ ハビリ病棟 (2014 年改定), 療養病棟 (2016 年改定), 介護医療院 (2018 年)などの診療報酬の改定に表れている。人口減少, 上記の医 療施策の誘導, 低侵襲治療をはじめとした新しい医療技術などを背 景として, 急性期病院は健全経営を保ちながら高回転運営を目指寸 ことになる。そのスキームは 9 日を目標とする入院の短期化, 短期 化による入院単価の上昇, そして病床回転率向上による患者数の維 持である ${ }^{2)}$ 。そのため急性期病院の高回転運営の要である入院の短 期化は，影響が大きい手術待ちの解消が課題となる。

一方，他建築種と同様に病院建築でも長期利用を目指すため，ま た度重なる需要の変更に対応するため, 部分的な増築や改築を繰り 返す場合が多い。病院建築は施設・人・物品・情報・経営を対象と し，持続的に職場環境の向上・生産性の向上・効率化などを目指寸 ことからファシリティマネジメント（以下 F M) の実行は課題で ある。また, 病院建築は規模の大きさ, 機能の複雑さ, 各部門の専 門性の高さから部門毎の F M も課題である。F M は米国で端を発し, 80 年代から日本でも導入されはじめ, 幾つかの実践例も報告されて いる ${ }^{3-6)}$ 。本報の調查対象である築約 20 年の $\mathrm{N}$ 病院でも次の大規模 整備に至るまで，F M として機能を維持・向上させるための長期 的・段階的な建築の整備と運用の改善が始まる。
そこで, 本報ではN 病院を地域中核的な急性期病院の一事例とし て位置づけ，今後の高回転運営の要となる手術部を対象とする。そ して病院側との協働体制で実践する F Mについて, 段階毎の使用後 評価・課題抽出・改善提案・改善のプロセスを報告し, 効果を検証 することを目的とする。まず本報では第 1 段階を報告する。

\section{2. 既往研究と研究の位置付け}

病院 F M 関して, 米山ら ${ }^{7)}$ は特定の病院での実践, 特に導入経 緯から経営的効果について報告した。手術部におけるサーキュレー ションと平面型に関して, 柳沢・今井ら ${ }^{8-10)}$ は物と人の動きから, 動きのモデル化を行い, 類型化した平面型に適応させることで問題 点を予測し, 評価した。手術部 F M $\mathrm{M}$ 念頭に置き, 加藤ら ${ }^{11,12)}$ は手 術室内の術中器材動線から物品管理方法を考察した。これらに対し, 本報は一事例の手術部を対象として F M の段階毎に直接的な前後 比較を行い，持続的に検証と改善を実践することに特徵がある。

\section{3. 研究の方法}

\section{1 対象病院}

$\mathrm{N}$ 病院が位置する市の人口は約 12 万人，高齢化率は約 $27 \%$ あ゙あ る。 $\mathrm{N}$ 病院の急性期病床は 420 床 (稼働病床の夕), 手術室は 8 室, 平面型は回収廊下型, 平均在院日数は 13.3 日, 年間手術件数は約

表 1 対象病院の概要

\begin{tabular}{ll|ll}
\hline 竣工年 & $: 1996$ 年 & 平均在院日数 & $: 13.3$ 日** \\
\hline 所在地 & $:$ 近畿地方 & 病床稼働率 & $: 81.2 \% * *$ \\
\hline 運営主体 $\quad:$ 市 & 一日平均外来患者数 & $: 1,146$ 人** \\
\hline 病床数 & $: 420$ 床* & 年間手術件数 & $:$ 約 4,300 件 \\
\hline 手術部看護師数 $: 26$ 名*** & 日勤看護師数 & $: 22 \sim 23$ 名*** \\
\hline 注** 一般病床のみ, 療養病床・回復期リ八病床・休止病床含まず \\
注** 2013 年度データ \\
注*** 2015 年度データ
\end{tabular}

京都府立大学大学院生命環境科学研究科 准教授 - 博士 (工学)

（干 606-8522 京都市左京区下鴨半木町 1-5）

帝塚山大学現代生活学部 准教授・博士 (工学)
Assoc. Prof., Graduate School of Life and Environmental Sciences, Kyoto Prefectural Univ., Dr. Eng.

2 Assoc. Prof., Faculty of Contemporary Human Life Science, Tezukayama Univ., Dr. Eng. 


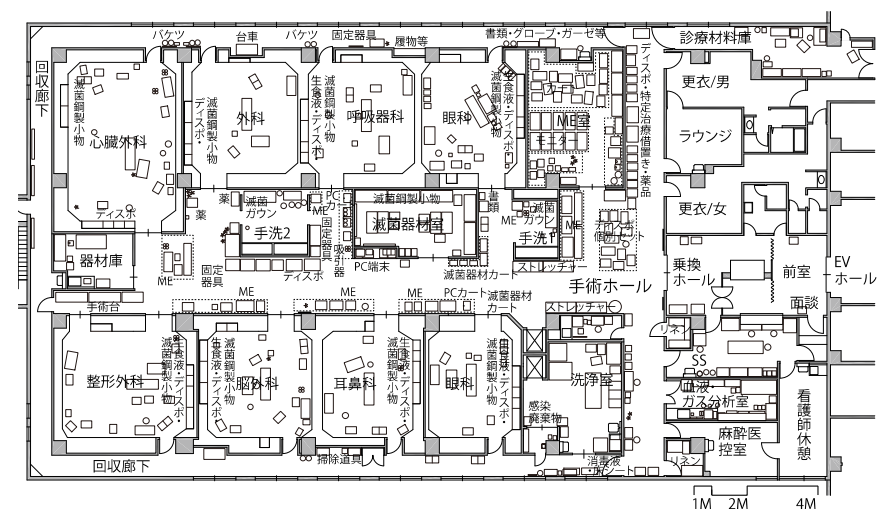

図 1 既存手術部平面図

4, 300 件（うち約 1,500 件は整形外科），日勤看護師は 22 23 名で 1 日あたり約 12 件の手術を行う (表 1 , 図 1)。

\section{2 手術部 FMの全体像と評価指標}

$\mathrm{N}$ 病院は 1996 年に竣工してから，一般的な増改築が行われてき た（表 2)。築 16 年を経た 2012 年 8 月に, 病院機能再構築整備を機 としてFMの実行が決定された。翌 2013 年 4 月に医師・看護師・ 経営担当事務員・運営担当事務員・整備担当事務員 - 建築設備担当 市役所員・建築設計事務所・医療コンサルタント・建築計画研究者 からなる協働体制が構築されたことが F Mの転機となる。病院の将 来像を描くに当たり, 地域の医療需要分析, その内 $\mathrm{N}$ 病院が受け持 つサービス規模とアクティビティを設定する中で, 手術件数はアク ティビティを示寸評価軸となる。そのため手術部 F M は重要課題と して掲げられた。その後のフローを表 2 に示す。手術部 F M は課題 に対して部分的な変更と効果の評価を繰り返し, 修正の方向性を都 度確認するため, 段階は改善に向けた変更毎に区分した。段階は, 現状を第 0 段階, F M 体制の構築から改善案の提示までを第 1 段階, 第 1 段階の提案に対する一部組織変更から改善案の提示までを第 2 段階, 手術部増築から改善案の提示までを第 3 段階, 物品レイアウ トと物品供給方式の変更から改善案の提示までを第 4 段階とした。 手術部 F Mの評価軸として, 相互関係が深いことから機能面は看 護の動きと物品の動き, 運営面は看護業務体制と物品管理・供給方 法, 施設面は平面形と物品配置, 経営面は人件費と設定し, 目標を 術前訪問等の充実による医療サービスの向上とした。手術部 F M の 実践に当たり，はじめに全体像と課題を把握する必要があるため, 第 1 段階にて実態把握を行う。

\section{表 2 手術部 F Mの全体像（第 4 段階まで）}

\begin{tabular}{|c|c|}
\hline $\begin{array}{l}\text { 第 } 0 \text { 段階 } \\
(1996.5 \sim)\end{array}$ & $\begin{array}{l}\text { 2001.9 MRI ・ 内視鏡室増築, } 2002.3 \text { 療養病棟増築, } 2011 \text { 人工透 } \\
\text { 析移転増床, } 2012 \text { 療養病棟一部を回復期 リ八病棟へ転換 } \\
2012.8 \text { 病院機能再構築 (手術部増築含む) - 病院 F M 実行決定 }\end{array}$ \\
\hline \multirow[t]{2}{*}{$\begin{array}{c}\text { 第 } 1 \text { 段階 } \\
(2013.4 \sim)\end{array}$} & $\begin{array}{l}\text { 変更 : 2013.4 F M協働体制の構築 } \\
\text { 病院全体実態把握, 手術部等増築案の検討, 手術キット化の検討 } \\
\end{array}$ \\
\hline & $\begin{array}{l}\text { 2014.6 11 手術部の実態把握 } \\
2015.2 \text { 手術部の機能評価・課題抽出・改善案の提示 (看護補助追 } \\
\text { 加と手術キット化導入案の廃止, 手術部増築平面案の修正, 物品 } \\
\text { レイアウト変更, 物品供給方式変更)・シシミンレシシン }\end{array}$ \\
\hline \multirow{2}{*}{$\begin{array}{l}\text { 第 } 2 \text { 段階 } \\
(2015.4 \sim)\end{array}$} & 変更 : 2015.4 看護補助員 2 名増員 \\
\hline & $\begin{array}{l}\text { 2015.6〜8 使用後評価・課題抽出・改善案の提示（物品レイアウ } \\
\text { ト変更, 物品供給方式変更)・シミュレーション }\end{array}$ \\
\hline \multirow{2}{*}{$\begin{array}{c}\text { 第 } 3 \text { 段階 } \\
(2015.8 \sim)\end{array}$} & 変更 : 2015.8 手術部増築 \\
\hline & 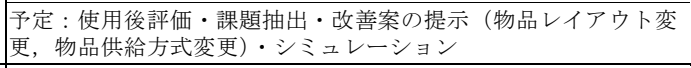 \\
\hline \multirow{2}{*}{$\begin{array}{c}\text { 第 } 4 \text { 段階 } \\
(\text { 予定 })\end{array}$} & 変更予定：物品レイアウト変更・物品供給方式変更 \\
\hline & 予定 : 使用後評価・課題抽出・改善案の提示・シミュレーション \\
\hline
\end{tabular}

\section{3 調査概要}

手術部の実態把握を目的とし，ヒアリング調查（看護体制，役割 分担, 物品管理 - 供給方式), 物品配置調查, 看護師追跡調查を行 った。概要を表 3 に記す。尚, 本調査は筆者の所属する京都府立大 学の倫理委員会にて承認を得た（受付番号 107）。

表 3 第 1 段階の手術部調査概要

\begin{tabular}{|c|c|c|}
\hline 調査項目 & 調査日 & 調査方法 \\
\hline $\begin{array}{c}\text { ヒアリング調査 } \\
\text { (看護体制) }\end{array}$ & $\begin{array}{c}2014 \text { 年 } \\
10 / 23\end{array}$ & 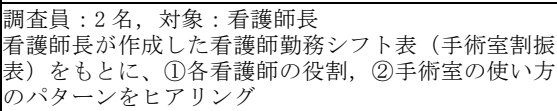 \\
\hline $\begin{array}{l}\text { ヒアリング調査 } \\
\text { (物品管理· } \\
\text { 供給方式) } \\
\end{array}$ & $\begin{array}{c}2014 \text { 年 } \\
10 / 23\end{array}$ & 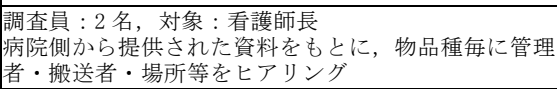 \\
\hline 物品配置調査 & $\begin{array}{c}2014 \text { 年 } \\
10 / 23 \\
11 / 13\end{array}$ & 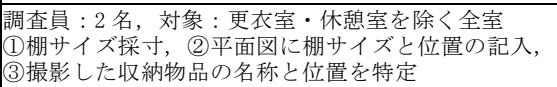 \\
\hline 看護師追跡調査 & $\begin{array}{c}2014 \text { 年 } \\
6 / 23\end{array}$ & 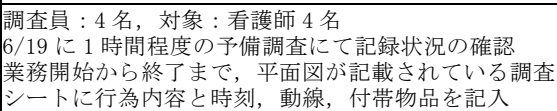 \\
\hline
\end{tabular}

\section{4. 第 1 段階の結果}

\section{1 看護体制と役割}

手術部の看護師の基本的な役割には, リーダーの役割と 1 つの手 術に対し割り振られる 3 つの役割がある。概要を以下に記す。 1)〈リーダー〉: 手術の進行状況を見て, 麻酔科医と次の手術開始時 刻を決定する。また当日看護師の担当变更, 休㮩開始の指示も行う。 2)〈器械出し〉: 術前は配盤, 術中は医師の指示に従い器械の手渡し, 術後は使用器械やガーゼの確認と後片付け・洗浄を行う。

3)〈外廻り〉: 術前訪問・申し送り，術中は不足物品の搬送・患者の 手術体位調整・心電図などの監視・記録，術後は申し送りを行う。 4)〈フリー補助〉: 器械出し, 外迴りのサポートを行う。

他に, 担当する手術前後の準備, 片付け, 物品管理などの〈支援〉 の役割は全員で行う。役割は固定されず, 午前と午後で担当する役 割が異なる場合が多い。看護補助員は 3 名配置され, 診療材料係, 器械係, 洗浄室係を担当する。

\section{2 手術室稼働パターン}

実際の手術室の稼働状沉から，手術室稼働パターンを(1)長時間， (2)午前・午後始まり, (3)遅始まり, (4)午後始まりに分類した (図 2)。 朝から始まる手術の準備は前日の夕方から概称行い, 当日は僅かな 準備のみとなる。(3)遅始まりは準備のピークをずらすためであり, 朝から準備する。また看護師は手術室に固定されておらず，午前と 午後で担当する室が異なる場合が多い。

看護師はその日の手術室の稼働パターン毎に, 担当する役割と室 が組まれる。つまりシフトが組みやすく, また臨機応変に対応でき る運営方法と言える。一方で業務を修得するまでに時間を要する。

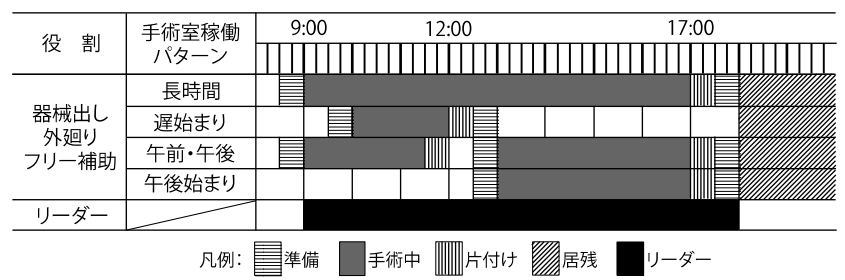

図 2 手術室稼働パターン 


\section{3 物品フローと物品配置}

既往研究 ${ }^{8)}$ を参考に, 物品の動きを定義する (図 3)。物品は機器, 器具, 消耗品の総称であるが, 動きの断面で分類する。状態変化に は, 使用後の污染や消毒・滅菌による性質変化, 複数の器具が集め られセット化される集合変化がある。保管数が定められ，使用まで の間に保管そのものが目的とされる保管と，保管という作業待ちの ために一時的に定められた場所に置かれている一時保管がある。

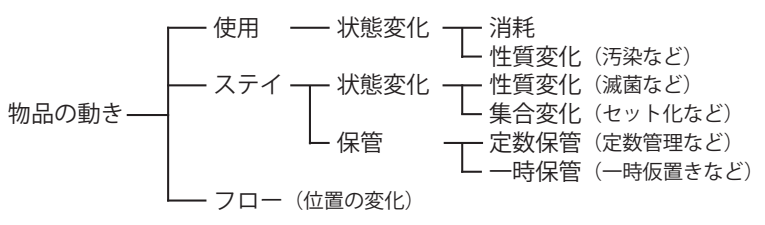

図 3 物品の動き

取り扱っている主な物品種毎に動きのサイクルの実態を整理す る（図 4)。物品は複数系統にて供給されている。ME 機器は概ね手 術室内の移動が主となるため, また掃除用具や用度物品などは本報 の主旨と異なるため省略する。サイクルと状態変化の動きを平面図 上に示す。紙面の都合上，典型的なサイクルとして滅菌鋼製小物／ コンテナとディスポ医療器具／定量配置型注 1) のみ例示する (図 5)。 1) 滅菌鋼製小物（メス, 鉗子, 鑷子, 舌圧子など）は, 直下階の中 央材料部で洗浄・滅菌され，ダムウェータで手術ホールに搬送され る。滅菌器材室で定量配置型にて補充される分, 各手術室で使用頻 度が高い物品が自主的定量型注 2)にて請求される分, 手術毎の個人 用コンテナがある。使用後，回収廊下経由にて洗浄室へ搬送され， 一次洗浄され，ダムウェータで中央材料部へ搬送される。

2) 衛生材料（ガーゼ, 包帯, マスクなど）は, 中央材料部で滅菌さ れダムウェータで手術ホールに搬送される。定量配置され, 手術患 者毎に必要な物品を集合させた個人セット（以下 個人セット）化 される。使用後は洗浄室内の区画に一時保管，廃棄される。

3) ディスポ医療器具（カテーテル, シリンジ，注射針など使い捨て の器具）は, 診療材料庫に納入される。手術ホールの棚で定量配置 型にて補充される分, 滅菌鋼製小物と同様に各手術室内で自主的定 量型にて請求される分がある。使用後, 回収廊下経由にて洗浄室内 のコーナーに一時保管され，廃棄される。

4) 薬剂は, 薬剂部に納入され, 手術室に搬送される。使用後に発生 するパッケージ等の廃棄物は, 回収廊下経由にて洗浄室内のコーナ 一に一時保管され，廃棄される。

各手術室内で自主的定量型で保管されている物品には予備も含 まれる。物品配置としては分散配置となる。術中の不足物品の調達 のための搬送動線は削減できるが，準備段階では余分に搬送動線が 生じる。滅菌鋼製小物とディスポ医療器具の個人セットの作成場所 が離れ，また一時保管場所もそれそれの作成場所と離れている。手 術室一の搬入は一元化されておらず, 各々搬入された後に手術室内 で配盤される。また回収廊下は倉庫化し, 清潔物品のストックと掃 除用具等が混在する。

\section{4 看護業務}

追跡調査対象看護師の役割, 術式を表 4 に示す。第 1 段階では状 況把握が目的で, 対象が 4 名だったため, 術式は参考として記載す る。人の動きは, 取る・置くといった「動作」の段階, 情報交換を

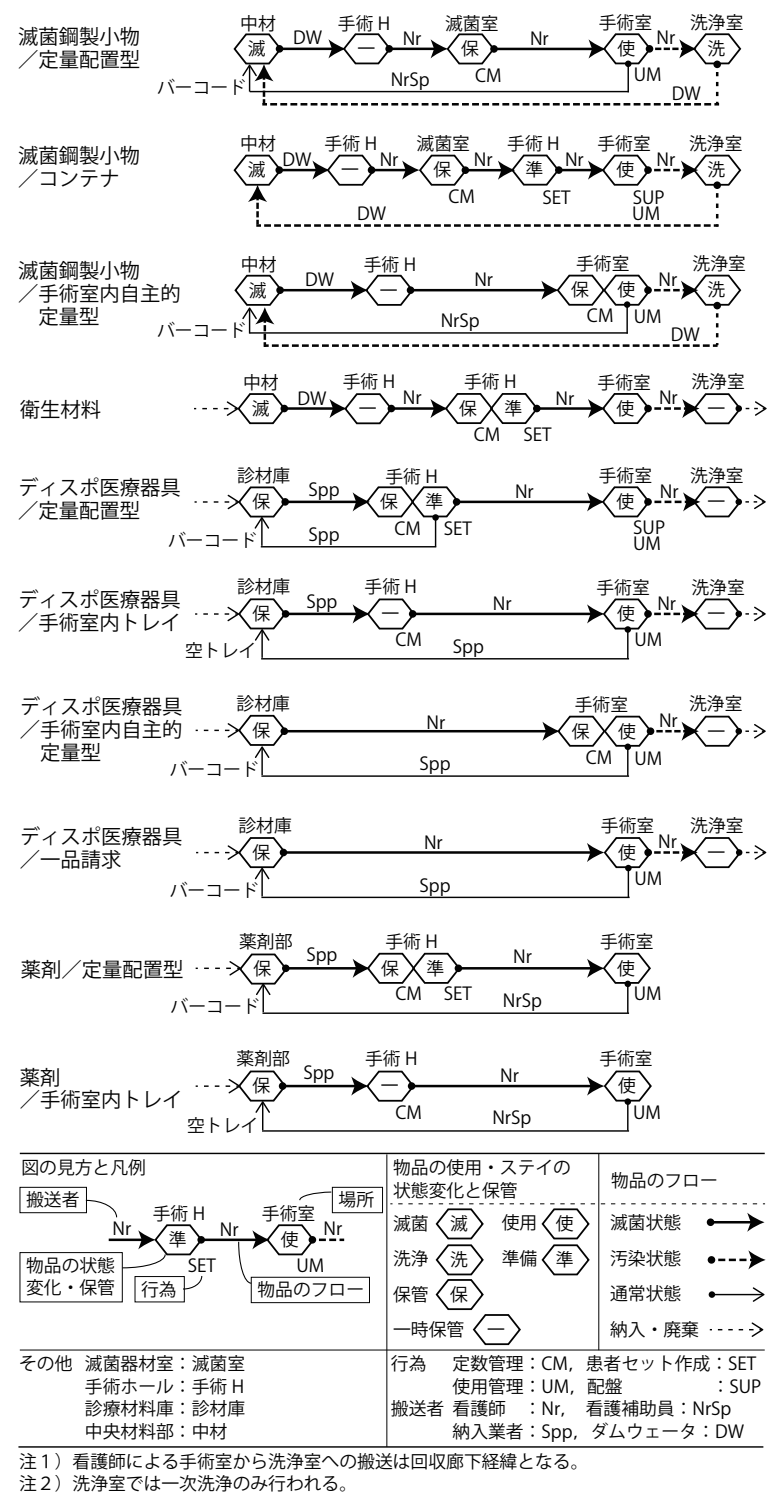

図 4 物品種毎のサイクルと状態変化

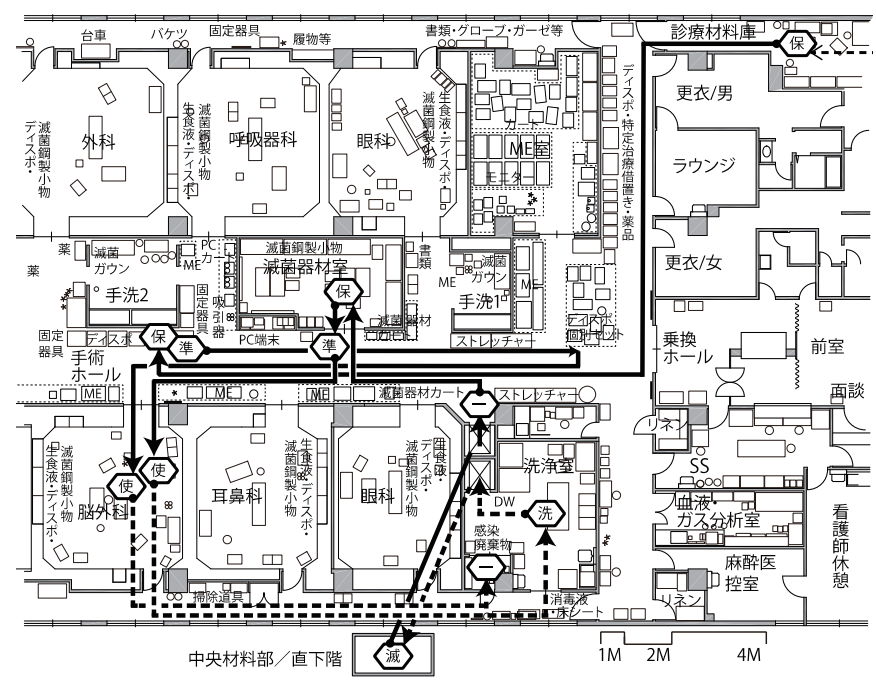

図 5 物品配置と滅菌鋼製小物/コンテナ。 ディスポ医療器具/定量配置のサイクル 
表 4 調查対象看護師の役割と術式

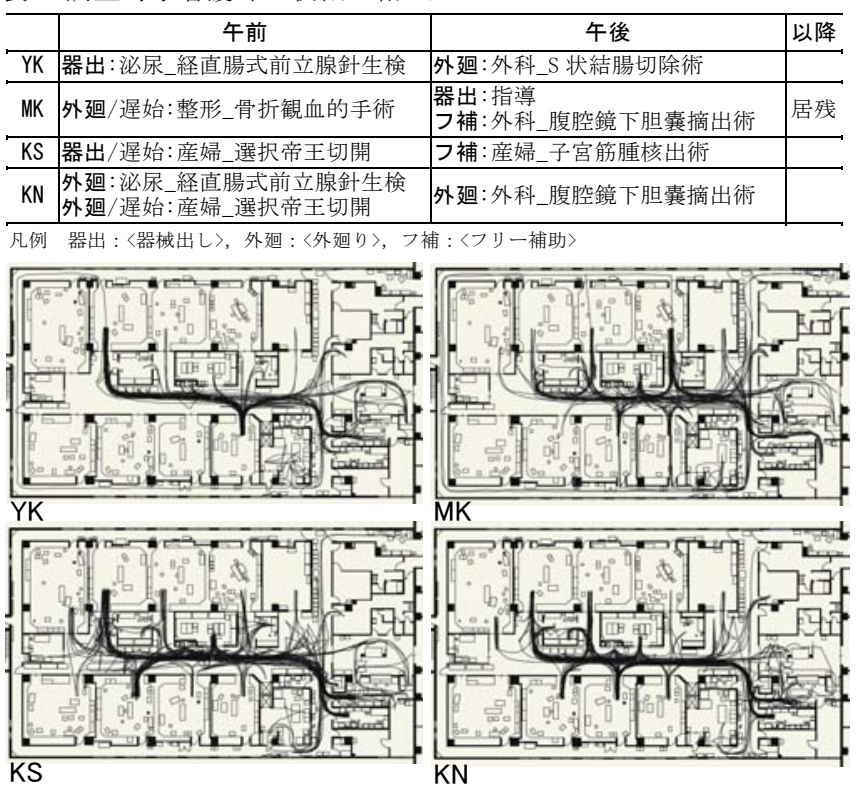

図 6 動線図
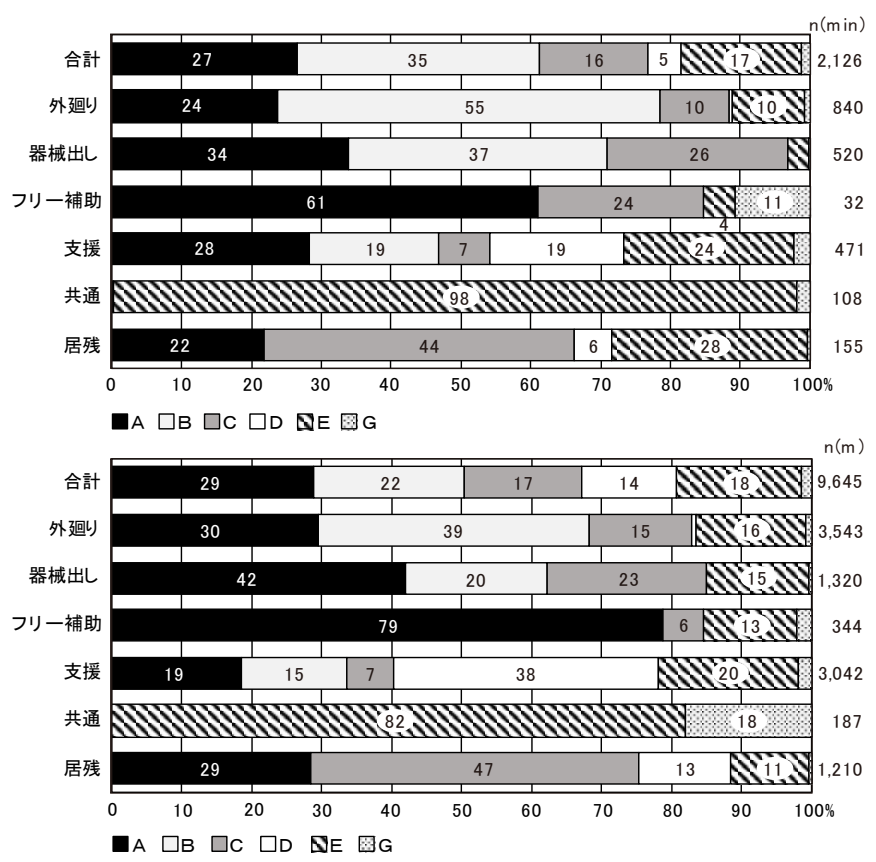

$\mathrm{A}$ : 手術準備（患者お迎え, 患者介助, 物品・ME 準備, 配盤, 情報確認など) $B$ : 手術介助 (器械出し, 物品・ME の調達, 手術介助, 術中記録など)

C : 後始末（術後患者介助, 清掃・片付け, 廃棄物の搬送, 器械洗浄など)

$\mathrm{D}$ ：物品管理（在庫の整理・期限碓認，器材の受け取り，定数管理など）

$\mathrm{E}$ : 術前訪問・情報収集・記録（術前訪問，カンファレンス, 看護記録など）

$\mathrm{F}$ : 管理（勤務表作成, 会議など), G : その他（実習生教育, 整頓など）

注）合計から「その他」の 2 分（看護業務時間），41m（看護動線量）除く

図 7 役割別看護業務時間の割合 (上) ・看護動線量の割合（下）

するといった「行為」の段階, 一連の行為を組み合わせた「作業」 の段階があり ${ }^{9)}$, 作業を内容別にまとめたものを「業務」と呼ぶ。 作業は動きが包括的なため, 空間内での動きの目的が明確化する行 為の段階で分析した。終日の各看護動線図を図 6 に, 役割別看護業 務時間の割合と看護動線量の割合を図 7 に示す。休悡時間を除く実 勤務時間の平均は 8 時間 52 分, 全看護動線量の平均は $2,421 \mathrm{~m}$ であ った。図 7 中の「共通」とは役割に関係なく, 全体で行う業務や全 員が各々行う業務，「居残」とは役割に関係なく日勤時間後にロー
テーションで当日の残務や翌日の準備を担う業務を示す。合計の [看護業務時間の割合・看護動線量の割合] は，A手術準備業務が $[27 \% \cdot 29 \%], \quad B$ 手術介助業務が $[35 \% \cdot 22 \%], C$ 後始末業務が $[16 \% \cdot 17 \%], \mathrm{E}$ 術前訪問・情報収集・記録業務が $[17 \% \cdot 18 \%]$ で あり，これらの業務で 9 割程度となる（図 7)。看護業務時間はB手 術介助業務の割合, 看護動線量は $\mathrm{A}$ 手術準備業務の割合が最も高い。

看護業務時間はく外迴り〉が最も多く840 分, 〈フリー補助〉が最も 少なく 32 分であった。看護動線量は〈外廻り〉と〈支援〉が $3,000 \mathrm{~m}$ 以 上，〈共通〉が最も少なく $187 \mathrm{~m}$ であった。次に各役割で, 看護業務 時間の割合の内 1 割超を占める業務について, 主な内訳を比較する。

1）〈外廻り>の主な内訳

(1) A 手術準備業務では患者介助が $43 \%$, 物品や ME 機器の準備が $35 \%$, (2) B 手術介助業務では物品や ME 機器の調達とセッティング が $24 \%$, 手術介助が $22 \%$, (3) E 術前訪問・情報収集・記録業務で は職員との情報交換が $95 \%$ を占める。

2)〈器械出し〉の主な内訳

(1)A 手術準備業務では物品やME 機器の準備と配盤が $62 \%$, (2) B 手術介助業務では手術介助が $34 \%$, (3) C 後始末業務では術後患者介 助が $54 \%$ 占める。

3)〈フリー補助〉の主な内訳

(1) A 手術準備業務では物品や ME 機器の準備が 100\%, (2) C 後始末 業務では清掃と物品後片付けが $81 \%$ を占める。

4）〈支援〉の主な内訳

(1) A 手術準備業務では手術稼働情報の確認が $46 \%$, (2) B 手術介助 業務では物品や ME 機器の調達とセッティングが $70 \%$, (3)D物品管 理業務では定数管理と物品補充が $68 \%$, (4) E 術前訪問・情報収集・ 記録業務では職員との情報交換が $52 \%$ を占める。

5）〈共通〉の主な内訳

(1) $\mathrm{E}$ 術前訪問・情報収集・記録業務では, 全員共通で朝の申し送 りとカンファレンスが 97\%を占める。

6)〈居残〉の主な内訳

(1) A 手術準備業務では物品や ME 機器の準備が 93\%, (2) C 後始末 業務では清掃と物品後片付けが $49 \%$, (3) E 術前訪問・情報収集・記 録業務では職員との情報交換が $69 \%$ を占める。

看護業務時間の割合よりも低い看護動線量の割合には，〈外廻り〉 と〈器械出し〉の B 手術介助業務がある。〈外迴り〉と言えども手術室 内業務が多く含まれている結果と考えられる。割合が高いものには， 〈フリー補助〉の $\mathrm{A}$ 手術準備業務，〈支援〉の D物品管理業務がある。 いずれも物品に関わる業務である。

\section{5 発着位置別にみた移動頻度と看護動線量}

調查対象者の移動頻度の合計 900 回のうち手術ホール発が最も多 く約 $33 \%$, 次いで手術室発が約 $27 \%$ であった（表 5)。手術ホール 発のうち手術室着が約 40\%, 手術室発のうち手術ホール着が約 $55 \%$ であり連携は強い。診療材料置場・滅菌器材発は約 8\%（計 74/900 回), 同着も約 9\%（79/900 回）であった。手術室と物品系諸室と の移動は, 調查時に術中の物品調達だけでなく, 準備時の個人セッ 卜作成時に手術室に自主的定量型で保管されている物品を頻繁に 取りに行く行動が見られた。手術室間の移動も同様の現象である。

同様に看護動線量の合計 $9,925 \mathrm{~m}$ のうち手術室発が最も多く約 $31 \%$, 次いで手術ホール発が約 $25 \%$ であった（表 6)。手術室発の 
うち手術ホール着が約 32\%, 手術ホール発のうち手術室着が約 37\% である。一方, 手術室と物品系諸室との看護動線量の割合（発着計 961/9926m, 約 10\%) は移動頻度の割合 (発着計 71/900 回, 約 8\%) であった。手術室間の看護動線量の割合 (493/9926m, 約 5\%) も移 動頻度の割合（25/900 回, 約 3\%) と同程度であった。調查時に散 見された手術室割振表（稼働予定と役割の記載，予定変更の手書き 修正）への移動は，手術室割振表着で 26/900 回，約 3\%であった。

表 5 発着位置別にみた移動頻度

\begin{tabular}{|c|c|c|c|c|c|c|c|c|c|c|}
\hline 発 & 看 & $\begin{array}{c}\text { 手術 } \\
\text { ホール }\end{array}$ & $\begin{array}{l}\text { 診療 } \\
\text { 材料 } \\
\text { 置場 } \\
\end{array}$ & $\begin{array}{c}\text { 滅菌 } \\
\text { 器材室 }\end{array}$ & 手術室 & $\begin{array}{c}\text { 回収 } \\
\text { 廊下/ } \\
\text { 洗浄 } \\
\end{array}$ & S S & \begin{tabular}{|l} 
手術室 \\
割振表
\end{tabular} & その他 & 合計 \\
\hline \multirow{2}{*}{$\begin{array}{l}\text { 手術 } \\
\text { ホール }\end{array}$} & 回 & 74 & 12 & 17 & 118 & 8 & 17 & 8 & 42 & 296 \\
\hline & $\%$ & 25.0 & 4. 1 & 5.7 & 39.9 & 2.7 & 5.7 & 2.7 & 14. 2 & 100.0 \\
\hline \multirow{2}{*}{$\begin{array}{l}\text { 診療材料 } \\
\text { 置場 }\end{array}$} & 回 & 11 & 5 & 0 & 18 & 0 & 1 & 1 & 0 & 36 \\
\hline & $\%$ & 30.6 & 13.9 & 0.0 & 50.0 & 0.0 & 2. 8 & 2.8 & 0.0 & 100.0 \\
\hline \multirow{2}{*}{$\begin{array}{l}\text { 滅菌 } \\
\text { 器材室 } \\
\end{array}$} & 回 & 17 & 0 & 0 & 16 & 0 & 2 & 1 & 2 & 38 \\
\hline & $\%$ & 44.7 & 0.0 & 0.0 & 42.1 & 0.0 & 5.3 & 2.6 & 5.3 & 100.0 \\
\hline \multirow{2}{*}{ 手術室 } & 回 & 134 & 19 & 18 & 25 & 8 & 12 & 7 & 23 & 246 \\
\hline & $\%$ & 54.5 & 7. 7 & 7. 3 & 10.2 & 3.3 & 4.9 & 2.8 & 9.3 & 100.0 \\
\hline \multirow{2}{*}{$\begin{array}{l}\text { 回収廊下 } \\
\text { /洗浄室 }\end{array}$} & 回 & 6 & 0 & 0 & 7 & 24 & 1 & 0 & 9 & 47 \\
\hline & $\%$ & 12.8 & 0.0 & 0.0 & 14.9 & 51.1 & 2. 1 & 0.0 & 19.1 & 100.0 \\
\hline \multirow{2}{*}{ S S } & 回 & 14 & 0 & 2 & 9 & 2 & 33 & 3 & 19 & 82 \\
\hline & $\%$ & 17. 1 & 0.0 & 2. 4 & 11.0 & 2.4 & 40.2 & 3.7 & 23.2 & 100.0 \\
\hline \multirow{2}{*}{$\begin{array}{l}\text { 手術室 } \\
\text { 割振表 } \\
\end{array}$} & 回 & 2 & 3 & 0 & 7 & 0 & 3 & 1 & 10 & 26 \\
\hline & $\%$ & 7.7 & 11.5 & 0.0 & 26.9 & 0.0 & 11.5 & 3.8 & 38.5 & 100.0 \\
\hline \multirow{2}{*}{ その他 } & 回 & 39 & 2 & 1 & 41 & 0 & 18 & 3 & 25 & 129 \\
\hline & $\%$ & 30.2 & 1.6 & 0.8 & 31.8 & 0.0 & 14.0 & 2.3 & 19. 4 & 100.0 \\
\hline \multirow{2}{*}{ 合計 } & 回 & 297 & 41 & 38 & 241 & 42 & 87 & 24 & 130 & 900 \\
\hline & $\%$ & 33.0 & 4.6 & 4.2 & 26.8 & 4.7 & 9.7 & 2. 7 & 14.4 & 100.0 \\
\hline
\end{tabular}

表 6 発着位置別にみた看護動線量

\begin{tabular}{|c|c|c|c|c|c|c|c|c|c|c|}
\hline 発 & 着 & $\begin{array}{l}\text { 手術 } \\
\text { ホール }\end{array}$ & $\begin{array}{l}\text { 診療 } \\
\text { 材料 } \\
\text { 置場 }\end{array}$ & $\begin{array}{c}\text { 滅菌 } \\
\text { 器材室 }\end{array}$ & 手術室 & $\begin{array}{ll}\text { 回収 } \\
\text { 廊下/ } \\
\text { 洗浄 } \\
\end{array}$ & S S & $\begin{array}{l}\text { 手術室 } \\
\text { 割振表 }\end{array}$ & その他 & 合計 \\
\hline \multirow{2}{*}{$\begin{array}{l}\text { 手術 } \\
\text { ホール } \\
\end{array}$} & $\mathrm{m}$ & 637 & 81 & 66 & 903 & 98 & 195 & 44 & 428 & 2451 \\
\hline & $\%$ & 26.0 & 3.3 & 2.7 & 36.8 & 4. 0 & 8. & 1.8 & 17.4 & 100.0 \\
\hline \multirow{2}{*}{$\begin{array}{l}\text { 診療材料 } \\
\text { 置場 }\end{array}$} & $\mathrm{m}$ & 69 & 13 & 0 & 246 & 0 & 15 & 35 & 0 & 378 \\
\hline & $\%$ & 18. 1 & 3.3 & 0.0 & 65.2 & 0.0 & 1.0 & 9.4 & 0.0 & 100.0 \\
\hline \multirow{2}{*}{$\begin{array}{l}\text { 滅菌 } \\
\text { 器材室 }\end{array}$} & $\mathrm{m}$ & 59 & 0 & 0 & 214 & 0 & 41 & 3 & 27 & 344 \\
\hline & $\%$ & 17.0 & 0.0 & 0.0 & 62.3 & 0.0 & 11.8 & 0.9 & 7.9 & 100.0 \\
\hline \multirow[t]{2}{*}{ 手術室 } & $\mathrm{m}$ & 1,006 & 285 & 216 & 493 & 206 & 346 & 69 & 480 & 3,102 \\
\hline & 70 & 32.4 & 9.2 & 7.0 & 15.9 & 6.7 & 11.2 & 2.2 & 15.5 & 100.0 \\
\hline \multirow{2}{*}{$\begin{array}{l}\text { 回収廊下 } \\
\text { /洗浄室 }\end{array}$} & $\mathrm{m}$ & 83 & 0 & 0 & 159 & 220 & 15 & 0 & 52 & 529 \\
\hline & $\%$ & 15.7 & 0.0 & 0.0 & 30.0 & 41.5 & 2.8 & 0.0 & 9.9 & 100.0 \\
\hline \multirow{2}{*}{ S S } & $\mathrm{m}$ & 209 & 0 & 43 & 233 & 27 & 115 & 30 & 398 & 1056 \\
\hline & $\%$ & 19.8 & 0.0 & 4.1 & 22.1 & 2.6 & 10.9 & 2.9 & 37.6 & 100.0 \\
\hline \multirow{2}{*}{$\begin{array}{l}\text { 手術室 } \\
\text { 割振表 }\end{array}$} & $m$ & 17 & 34 & 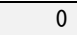 & 77 & 0 & 26 & 47 & 0 & 202 \\
\hline & $\%$ & 8.6 & 16. 7 & 0.0 & 38.3 & 0.0 & 13.0 & 3.2 & 0.0 & 100.0 \\
\hline \multirow{2}{*}{ その他 } & $\mathrm{m}$ & 401 & 32 & 28 & 878 & 0 & 205 & 47 & 274 & 1,864 \\
\hline & $\%$ & 21.5 & 1.7 & 1.5 & 47.1 & 0.0 & 11.0 & 2.5 & 14.7 & 100.0 \\
\hline \multirow{2}{*}{ 合計 } & & 2480 & 44 & 353 & 3204 & 552 & 958 & 275 & 1659 & 9926 \\
\hline & 70 & 25.0 & 4.5 & 3.6 & 32.3 & 5.6 & 9.7 & 2.8 & 16.7 & 100.0 \\
\hline
\end{tabular}

注）発着は作業位置から, 次の作業位置を示し, 通過の位置は含まれない。

5. 考察とシミュレーション

\section{1 課題}

運営面, 施設面, 機能面, 経営面の課題を以下に挙げる。

1) 運営面

物品管理・供給方法として物品種毎の定量配置型, 手術室内で自 主的定量型, 一品請求型, 借置き型が混在する。看護補助員が 3 名 のみのため, 複数の方式で, 定数管理からセットアップ, 供給まで を看護師が担うこととなり負担が大きい。

2)施設面

物品は分散配置され，また滅菌鋼製小物とディスポ医療器具の保 管場所, 個人セット作成場所, 一時保管場所が異なる。よって準備, 配盤時の手術室への搬送が一元化されず非効率である。また個人セ
ット作成に定量配置にない物品を手術室内から探して回る移動も 非効率と言える。

回収廊下が倉庫化していることは，保管スペース量と保管スペー スの分散化による定数管理の手間に一因があると考える。

3)機能面

手術準備業務にかかる看護業務時間と看護動線量は約 $30 \%$ を示 した。物品管理・供給方法と物品の分散配置も関連して, 負担が増 している。特にくフリー補助〉の負担は他の役割と比較して相対的に 大きい。

4)経営面

$\mathrm{A}$ 手術準備業務の内, 物品や ME 機器の準備は看護業務時間の全 体の約 $11 \%$ を占め, 一人当たり平均で約 60 分かかっていた。手術 準備業務には看護師という専門職でなくとも担うことができる業 務は多々ある。専門職が患者サービスに最大限従事しているとは言 い難い。

\section{2 提案}

改善目標は術前訪問等の充実による質的な医療サービスの向上 であることを念頭に置き，下記提案が行われた。

1)物品配置の中央集約化

ディスポ診療材料・滅菌鋼製小物・衛生材料，そして手術室内の 自主的定量型分も中央保管し, 準備 - 管理のための時間と移動距離 を軽減する。

2)個人セット作成と搬送の一元化

物品管理・供給方法として個人セット作成に着目し, 中央集約化 化された保管庫で一元的に個人セットを作成し, 搬送ロスを軽減す る。また手術部内の自主的定量型を廃止することで管理の手間が削 減できるが，予備や多頻度使用物品は手術毎に予備カートとしてセ ット交換型の様に搬送する。

3) 準備作業の負担

これまで準備作業は看護師が中心的に行ってきたが，物品配置の 中央集約化と物品管理・供給方法の一元化を図った上で, 看護補助 員を担当として増員し, 物品や ME 機器の準備に関わる看護師の時 間と動線量を軽減する。これにより目標の術前訪問等の充実を図る。

\section{3 シミュレーションと今後の展開}

まず目標に対する上記提案の妥当性を検証するため, 調査対象者 の一人である KS の動きをサンプルとする。KS は，午前は遅始まり のため〈支援〉で手術準備業務と物品管理業務，午後からくフリー補 助〉で，手術準備業務の影響を図ることができると考えた。シミュ レーション条件は，(1)ディスポ診療材料・滅菌鋼製小物・衛生材料 の配置の中央集約化, (2)物品供給方法を個人セットと予備カートの カート供給に変更, (3)個人セット作成・物品管理担当看護補助員を 追加，とした。

追跡調査原票へ上記条件を反映させ，再集計した結果を表 7 に示 す。全体として, 個人セット作成・物品管理担当看護補助員の追加 の影響が大きく, KS の当日の役割の場合, 計約 54 分・ $800 \mathrm{~m}$ の削減 の可能性がある。手術室内業務が中心のく器械出し〉の場合は，より 削減の可能性が小さいと考える。

手術管理業務への影響は僅かで, 約 3 分・90mの削減であり, 影 響は小さい。理由は, 物品・ME 機器などの準備ではあるが，手術室 内での ME 準備や手術室内からの物品の取り揃えは看護師が行うた 
めと考えられる。

物品管理業務は最も影響を受け, 約 50 分・ $690 \mathrm{~m}$ の削減の可能性 がある。〈支援〉の場合, 翌日の個人セットの作成, 各手術室の材庫 確認・使用期限チェック・補充を行っていたため, その業務ごと看 護補助員に委託可能だったためである。

今回は, 計約 54 分・ $800 \mathrm{~m}$ の削減の可能性を明らかにしたが, FM としては全役割を通して全体としてどの程度の効率化になるのか, 効率化された時間がどの程度患者サービスの向上につながる時間 に還元されるのかを検証することが今後の課題である。

次報にて，第 2 段階として，目標の一部変更として実際に看護補 助員を 2 名追加したため, 使用後評価, 改善点のシミュレーション を行う予定である。

表 7 シミュレーション前後比較

\begin{tabular}{|c|c|c|c|c|c|c|}
\hline & 前 & 後 & \multirow[b]{2}{*}{ 差 } & \multicolumn{3}{|c|}{ 前 後 } \\
\hline & $\begin{array}{l}\text { 業務 } \\
\text { 時間 } \\
\text { (分) }\end{array}$ & $\begin{array}{l}\text { 業務 } \\
\text { 時間 } \\
\text { (分) }\end{array}$ & & $\begin{array}{l}\text { 距離 } \\
\text { (m) }\end{array}$ & $\begin{array}{c}\text { 距離 } \\
\text { (m) }\end{array}$ & 差 \\
\hline A 手術準備業務 & 166.3 & 163.1 & 3.2 & 801 & 712 & 89 \\
\hline 患者の移動・お迎え & 8.0 & 8.0 & & 44 & 44 & \\
\hline 患者直接介助・麻酔支援 & 42.3 & 42.3 & & 36 & 36 & \\
\hline 物品・ME機器などの準備 & 66.0 & 62.9 & 3.2 & 525 & 436 & 89 \\
\hline 配盤 & 49.6 & 49.6 & & 196 & 196 & \\
\hline 患者受け渡し & 0.3 & 0.3 & & 0 & 0 & \\
\hline B 手術介助業務 & 96.8 & 96.8 & 0.0 & 377 & 377 & 0 \\
\hline 物品・ME機器の調達・設定, 手術介助 & 48.2 & 48.2 & & 171 & 171 & \\
\hline 術中記録 & 14.5 & 14.5 & & 0 & 0 & \\
\hline 室内外での情報交換 & 0.5 & 0.5 & & 10 & 10 & \\
\hline 術中の後片付け & 27.1 & 27.1 & & 156 & 156 & \\
\hline その他 & 6.5 & 6.5 & & 40 & 40 & \\
\hline C 後始末業務 & 35.3 & 35.0 & 0.3 & 248 & 228 & 20 \\
\hline 術後の患者介助・送り出し & 17.3 & 17.3 & & 4 & 4 & \\
\hline 清掃・物品・ME機器の後片付け & 9.2 & 9.2 & & 72 & 72 & \\
\hline 使用済みリネン・廃棄物の搬送 & 0.3 & 0.0 & 0.3 & 20 & 0 & 20 \\
\hline 未使用物品の収納 & 5.6 & 5.6 & & 69 & 69 & \\
\hline 他の後片付け業務 & 2.0 & 2.0 & & 67 & 67 & \\
\hline その他 & 1.0 & 1.0 & & 15 & 15 & \\
\hline D 物品管理業務 & 58.9 & 8.7 & 50.2 & 844 & 159 & 685 \\
\hline 在庫の整理・期限チェック & 27.7 & 4.8 & 22.9 & 386 & 53 & 333 \\
\hline 手術物品の取り 揃え・チェック・補充 & 29.7 & 3.5 & 26.1 & 451 & 105 & 346 \\
\hline その他 & 1.6 & 0.3 & 1.3 & 7 & 1 & 6 \\
\hline E 術前訪問·情報収集·記録記入業務 & 112.4 & 112.4 & 0.0 & 415 & 415 & 0 \\
\hline 情報確認・ワークシート記入・処方箋 & 0.3 & 0.3 & & 0 & 0 & \\
\hline 術前の病棟訪問 & 38.8 & 38.8 & & 54 & 54 & \\
\hline 看護記録の作成 & 0.7 & 0.7 & & 20 & 20 & \\
\hline 情報交換・カンファレンス・申し送り & 67.8 & 67.8 & & 282 & 282 & \\
\hline その他 & 4.8 & 4.8 & & 59 & 59 & \\
\hline G その他 & 14.3 & 14.3 & 0.0 & 57 & 57 & 0 \\
\hline 看護学生・実習生の教育 & 9.7 & 9.7 & & 21 & 21 & \\
\hline 廊下・手術室などの整理整頓 & 4.0 & 4.0 & & 10 & 10 & \\
\hline その他 & 0.7 & 0.7 & & 27 & 27 & \\
\hline 合計 & 484.0 & 430.3 & 53.7 & 2743 & 1949 & 794 \\
\hline
\end{tabular}

謝辞

本調查は, 2015 年度京都府立大学大学院生命環境科学研究科博士前期課程 の青木洋美氏の修士論文の一部として行われたものである。青木氏に感謝申 し上げます。

\section{注䣋}

1)物品材庫管理に関わる「定量」という用語は, 「定数」と称される場合も 多々ある ${ }^{13)}$ 。筆者は既往研究 ${ }^{14,15}$ にとて定量配置型という用語を既に用いてい ることから，本報でも定量配置型を用いることとする。

2) 自主的定量型とは, 使用部にて定数が自主的に設定され, 使用分が使用の 都度請求される方式を指す。

\section{参考文献}

1)朝日新聞, 2014.2.13

2) 金善一，鈴木賢一，柳澤忠他：病院活性化と平均在院日数に関する研究, 日本建築学会計画系論文集 第 456 号, pp. 103-110, 1994.2

3) 安藤亨, 今井正次 : 庁舎のオフィス改修における 3 段階プロセス -三重県 庁 F M 改修モデルに関寸る研究-, 日本建築学会技術報告集 第 15 巻 第 30 号, pp. 487-492, 2009.6

4) 恒川和久, 松岡利昌, 谷口元 : 大学における施設運営費ベンチマーキング に関する研究, 日本建築学会技術報告集 第 15 巻 第 29 号, pp. 295-300, 2009.2

5) 脇坂圭一, 恒川和久, 太幡英亮, 松岡利昌 : 国立大学における点検および 評価から見た施設維持管理手法に関する研究, 日本建築学会技術報告集 第 21 巻 第 47 号, pp. 333-338, 2015.2

6) 恒川和久, 柴田美里, 太幡英亮, 村上心, 川野紀江, 納村信之, 松岡利昌 : 公共施設におけるアクティビティの分析と考察 一アクティビティとキャ パシティに着目した公共施設マネジメントに関する研究 その 1-, 日本建 築学会計画系論文集 第 80 巻 第 717 号, pp. 2617-2624, 2015. 11

7) 米山剛史, 辻野純徳, 荻原みき: 病院における FM による医療・経営環境 の継続的改善の効果 一倉敷中央病院の事例報告: 経営者・医療者・設計者 が三位一体となった FM その 2-, 日本建築学会大会学術講演梗概集, pp. 1231-1232, 2010.9

8) 柳沢忠, 今井正次, 谷口元 : 中央手術部のサーキュレーションに関する研 究・その 1 -人の動きのモデル化と予測の方法-, 日本建築学会論文報告集 第 225 号, pp. 41-45, 1974. 11

9)柳沢忠, 今井正次, 谷口元 : 中央手術部のサーキュレーションに関する研 究・その 2 -人の動きのモデル化と予測の方法-, 日本建築学会論文報告集 第 226 号, pp. 63-71，1974. 12

10) 柳沢忠, 今井正次 : 中央手術部のサーキュレーションに関する研究 (その 3）一管理方式と空間構成のパターン化-, 日本建築学会論文報告集 第 236 号, pp. $69-78$, 1975.10

11) 福原涼平, 加藤彰一, 毛利志保 : 器材の動線からみた手術室の運用に関 する研究 -病院手術部のファシリティマネジメントに関する研究-, 日本 建築学会大会学術講演梗概集, pp. 177-178, 2015.9

12) 福原涼平, 毛利志保, 篠原佳則, 加藤彰一 : 子ども病院の術中の手術室 内における物品の移動を伴う看護師の動線に関寸る研究 - 手術部門サ一 キュレーションのシミュレーションに関寸る研究-, 日本建築学会東海支 部研究報告集 第 54 号, pp. 325-328, 2016.2

13) 日本病院管理学会情報・用語委員会編 : 医療・病院管理用語辞典〔改訂 版]，エルゼビア・ジャパン, 2003

14) 河合慎介, 今井正次 : 物品の流れからみた物品管理・供給システムのモ デル評価 -病院の部門間連携に関する研究 1 -, 日本建築学会計画系論文 集 605 号, pp. 55-62，2006.7

15) 河合慎介, 今井正次 : 物品管理・供給システムからみた物品搬送量 一病 院の部門間連携に関する研究 $2-$, 日本建築学会計画系論文集 613 号, pp. $45-52,2007.3$

[2018 年 6 月 6 日原稿受理 2018 年 7 月 31 日採用決定］ 